\title{
INVESTIGACIÓN
}

\section{Characterization of crude and purified pumpkin seed oil}

\author{
By John Tsaknis, Stavros Lalas and Evangelos S. Lazos*
}

\section{Department of Food Technology, Faculty of Food Technology and Nutrition Technological Educational} Institution of Athens. Agiou Spiridonos Str., Egaleo 12210 Athens, Greece.

\section{RESUMEN}

Caracterización de aceite de semilla de calabaza crudo y purificado.

Aceite de semillas de calabaza descascarada (Cucurbita pepo y Cucurbita maxima) fue extraído con éter de petróleo caliente, y luego desgomado, neutralizado y decolorado consecutivamente. Las características físicas y químicas de aceites crudo y purificado fueron determinadas. La densidad, el índice de refracción, la viscosidad y el índice de peróxido no se afectaron por la purificación, mientras que se observó una disminución en la acidez, color, insaponificable, $E^{1 \%} 1 \mathrm{~cm} 232$, y estabilidad oxidativa, y un aumento en el punto de humo y de $\mathrm{E}^{1 \%} \mathrm{~cm} 270$. La purificación no afectó los perfiles de ácidos grasos y esteroles. El análisis CGL para la composición de ácidos grasos del aceite de semilla mostró que los insaturados predominantes fueron linoleico $(42 \%)$ y oleico $(38 \%)$, mientras que los saturados mayoritarios fueron palmítico $(12,7 \%)$ y esteárico $(6 \%)$. Sólo el $a$-tocoferol fue detectado a nivel de $126 \mathrm{mg} / \mathrm{kg}$, el cual se redujo a $78 \mathrm{mg} / \mathrm{kg}$ después de la purificación. Los principales esteroles de la materia insaponificable del aceite de semilla de algodón fueron $\Delta^{7,22,25}$-stigmastatrien-3ßol, a-spinasterol, $\Delta^{7,25}$ - stigmastadienol y $\Delta^{7}$-avenasterol, seguidos por el stigmasterol, 24-metilcolest-7-enol y $\Delta^{7}$. stigmastenol, y también se encontraron trazas de componentes menores de colesterol, brasicasterol, campesterol, sitostanol, $\Delta^{5}$. avenasterol, eritrodiol y uvaol.

PALABRAS-CLAVE: Aceite de semilla de calabaza Característica física - Característica química - Refinación.

\section{SUMMARY}

Characterization of crude and purified pumpkin seed oil.

Oil from hulled pumpkin seeds (Cucurbita pepo and Cucurbita maxima) was extracted with hot petroleum ether, and then it was degummed, neutralized and bleached, consecutively. Physical and chemical characteristics of crude and purified oils were determined Density, refractive index, viscosity and peroxide value were not affected by purification, while decreases in acidity, colour, unsaponifiable, $\mathrm{E}^{1 \%}{ }_{1 \mathrm{~cm}} 232$, and oxidative stability, and increases in smoke point and $E^{1} \%{ }_{1} \mathrm{~cm} 270$ were observed. Purification did not affect the fatty acid and sterol profiles. GLC analysis for the fatty acid composition of the seed oil showed that the predominan unsaturates were linoleic $(42 \%)$ and oleic $(38 \%)$, while the major saturates were palmitic $(12,7 \%)$ and stearic $(6 \%)$. Only a-tocophero was detected at a level of $126 \mathrm{mg} / \mathrm{kg}$, which reduced to $78 \mathrm{mg} / \mathrm{kg}$ after purification. The main sterols of pumpkin seed oil unsaponifiable were $\Delta^{7,22,25}$,-stigmastatrien-33-ol, $a$-spinasterol, $\Delta^{7,25}$-stigmastadienol and $\Delta^{7}-$ avenasterol, followed by stigmasterol, 24-methylcholest-7-enol and $\Delta^{7}$-stigmastenol, and also trace to minor amounts of cholesterol, brassicasterol, campesterol, sitostanol, $\Delta^{5}$-avenasterol, erythrodiol and uvaol were found.

KEY-WORDS: Chemical characteristic - Physical characteristic - Pumpkin seed oil - Refining.

\section{INTRODUCTION}

Cucurbit seeds are used widely in many countries for oil or protein production. In Nigeria, such seeds are used for oil extraction at the village level $(1,2)$. Pumpkin seed oil has a special place among edible oils produced in Yugoslavia, while large quantities of this oil are produced in Austria, Hungary and southern parts of the former USSR (3). In Greece, no oil or protein from such seeds has been produced, but pumpkin seeds are consumed in significant amounts as a snack in the form of salted roasted seeds, constituting a food rich in oil and protein $(4,5)$.

The chemical characteristics of various cucurbit seed oils as well as work on edibility and stability have been reported $(2,4,6,7)$. The oil content of various cucurbit seeds varied from 38 to $60 \%(3,4,8)$. The main fatty acids of pumpkin seed oil are linoleic and oleic. Due to its high content in unsaturated fatty acids, it has been suggested as a substitute for highly unsaturated oils in diets (4). More recently, the behaviour of pumpkin seed oil during heating has been investigated by Lazos et al., (5) Oil composition can affect its behaviour during heating and processing and hence, more details on pumpkin seed oil are needed.

The purpose of this study was to present more data on pumpkin seed oil components as well as to determine the effect of purification on them.

\section{MATERIALS AND METHODS}

\section{Sample preparation and oil purification}

Ripe fruits of Cucurbita pepo and Cucurbita maxima were collected from farms in Prangi- 
Didymotikhon area, Evros, Greece, in August 1996. The ripe fruits were crushed and the seeds separated, washed and sun-dried. The sun-dried seeds were hulled and then ground to a powder by a Brabender mill to pass through a $1.00 \mathrm{~mm}$ sieve. Batches of ground seeds were extracted for $15 \mathrm{hr}$ with petroleum ether (b.p. $40-60^{\circ} \mathrm{C}$ ) in $2 \mathrm{~L}$ Soxhlet extractors. The solvent was evaporated under reduced pressure, and the oils from different batches were combined and kept in sealed bottles under refrigeration $\left(0-4^{\circ} \mathrm{C}\right)$ for further processing and analysis.

Pumpkin seed oil was degummed using the following procedure. Fifty grams of oil were put in 100 $\mathrm{mL}$ capacity pyrex test tubes and then were immersed in a water-bath adjusted at $90^{\circ} \mathrm{C}$. Afterwards, a $3 \%$ $(\mathrm{w} / \mathrm{w})$ water at $80^{\circ} \mathrm{C}$ and $0,3 \%(\mathrm{w} / \mathrm{w})$ phosphoric acid were added under continuous stirring. The mixture was stirred for $10 \mathrm{~min}$, cooled, centrifuged for $5 \mathrm{~min}$ at 3000 rpm, and decanted to obtain degummed oil.

Batches of $500 \mathrm{~g}$ of oil were put into $1 \mathrm{~L}$ beakers, heated at $80^{\circ} \mathrm{C}$, and then $4,5 \mathrm{~mL}$ of $4.125 \mathrm{M} \mathrm{NaOH}$ were added under continuous stirring. Stirring was continued for 40 min to coagulate the soap, and then left to stand for soap separation. Most of the neutralized oil was obtained by decanting, and the remaining soap-stock was centrifuged at $3000 \mathrm{rpm}$ for further oil separation. Afterwards, the oil was transferred into a separatory funnel and was washed with $15 \%(\mathrm{w} / \mathrm{w})$ distilled water $\left(80^{\circ} \mathrm{C}\right)$ by shaking vigorously the separatory funnel, and allowed to stand for $15 \mathrm{~min}$. The lower aqueous layer was separated and discarded.

The purified oil was heated at $105^{\circ} \mathrm{C}$ for moisture removal, and afterwards, was bleached by adding $3 \%$ Tonsil Optimum earth technical powder, plus $2 \%$ activated carbon. The mixture was stirred for $15 \mathrm{~min}$ and then filtered under vacuum using a Whatman No 1 filter paper. The colour of the oil as measured by a Lovibond tintometer was changed from the initial 10,9 red and 15 yellow units to 5,0 red and 3,2 yellow units.

\section{Analytical procedures}

Free fatty acids (FFA), peroxide value (PV), and ultra-violet absorption at 232 and $270 \mathrm{~nm}$ were determined using the IUPAC methods (9). lodine value (IV) was determined using the Wijs method as described by Pearson (10). Refractive index of the oil was measured at $40^{\circ} \mathrm{C}$ with an Abbe refractometer with temperature adjustment; colour was measured with a Lovibond tintometer; viscosity was measured using a Brookfield LVT rotational viscometer equipped with a No 2 spindle rotated at $60 \mathrm{rpm}$ at $21^{\circ} \mathrm{C}$; and smoke point with a method adapted from that described by BS 648: Section 1,8 (11). Oil stability was evaluated using the Rancimat method using the Rancimat 679 until the oil batch reached the temperature of $120^{\circ} \mathrm{C}$ and with an air flow rate set at
20L/hr. Extra virgin olive oil and sunflower oil were examined concurrently for comparison reasons.

Fatty acids were characterized by gas-liquid chromatography (GLC). The fatty acid methyl esters (FAME) were prepared according to the following method. About $25 \mathrm{mg}$ of oil was accurately weighed into a screw cap tube and $1,5 \mathrm{~mL} 0,5 \mathrm{M}$ methanolic sodium hydroxide was added, mixed and heated at $100^{\circ} \mathrm{C}$ for 7 minutes. After cooling $2 \mathrm{~mL}$ of boron trifluoride was added and heated at $100^{\circ} \mathrm{C}$ for 5 minutes. The tube was cooled to $30-40^{\circ} \mathrm{C}$ and $1 \mathrm{~mL}$ iso-octane was added, capped and shaken using a whirli mix for 30 seconds. $5 \mathrm{~mL}$ of saturated sodium chloride solution was immediately added and the tube was shaken again. The tube contents were allowed to separate and the top (iso-octane containing FAME) layer was removed and the lower layer was reextracted with an additional $1 \mathrm{~mL}$ iso-octane. The two iso-octane extracts were combined, dried over anhydrous sodium sulfate if necessary, and concentrated to approximately $1 \mathrm{~mL}$ using a nitrogen stream.

The analysis of FAME were performed with a Carlo Erba 5600 gas-liquid chromatograph equipped with a $50 \mathrm{~m}, 0,22 \mathrm{~mm}$ ID, 0,25 $\mu \mathrm{m}$ thickness, BPX 70 CP-Sil 88 capillary column. Operating conditions were as follows: Helium flow rate $25,6 \mathrm{~mL} / \mathrm{min}$; injector and detector (FID with hydrogen flow $\mathrm{mL} / \mathrm{min}$ and air flow $450 \mathrm{~mL} / \mathrm{min}$ ) temperatures were $235^{\circ} \mathrm{C}$. The temperature programme was $160-210^{\circ} \mathrm{C}$ at a rate of $1,5^{\circ} \mathrm{C} / \mathrm{min}$, initial time at $160^{\circ} \mathrm{C}$ was $0,0 \mathrm{~min}$ and final time at $210^{\circ} \mathrm{C}$ was $5,0 \mathrm{~min}$. Methyl esters were identified and quantified by comparing the retention time and peak area of the unknowns with those of FAME standards (British Greyhound, Chromatography and Allied Chemicals).

Tocopherols were determined by high performance liquid chromatography (HPLC) using a modification of Carpenter's method (12). One gram of oil was accurately weighed into a 3 dram sample vial wrapped in foil paper to prevent oxidation. The oil was dissolved in $5 \mathrm{~mL} n$-hexane, HPLC grade, before injection. A 20 $\mu \mathrm{L}$ sample was injected into a Waters $600 \mathrm{E}$ HPLC fitted with a $\mu$-Polarsil, $125 \AA, 10 \mu \mathrm{m}, 3,9 \times 300 \mathrm{~mm}$ HPLC column with the following characteristics: irregularly-shaped silica. Detection was made with a Waters 486 Tunable Absorbance Detector set at 295 $\mathrm{nm}$. Iso-propanol: n-hexane:absolute ethanol $(2: 97,5: 0,5)$ at $1 \mathrm{~mL} / \mathrm{min}$ was used as mobile phase. Waters Baseline 815 programme running on a computer was used as integrator for the determination of the standard calibration curves and for the calculation of the amounts of tocopherols in the oil samples. Tocopherols obtained from Merck (DL- $\alpha$-tocopherol) and Sigma [(+)- $\delta$-tocopherol], were used as standards.

Unsaponifiable matter and sterols were determined using the standard method of the Official Journal of the European Communities (13). Unsaponifiables were prepared by saponification with ethanolic $\mathrm{KOH} 2 \mathrm{M}$, 
washing and ether extraction using $50 \mu \mathrm{L} / 5 \mathrm{~g}$ solvent of a $0,2 \%$ a-cholestanol solution as an internal standard. Sterolic fraction was separated by TLC using silica gel plates, developed with a 65:35 (v/v) hexane:ethyl ether mixture, spraying with 2,7dichlorofluorescein, scraping and extracting with chloroform and ethyl ether. Sterols were converted to trimethylsilyl (TMS) ethers using a silylation reagent consisting of a 9:3:1 (v/v/v) mixture of pyridine:hexamethyldisilazane:trimethylchlorosilane in the ratio of $50 \mu \mathrm{L}$ for every milligram of sterols. The measurement was done on a Carlo Erba 5600 Gas Chromatograph using a $25 \mathrm{~m} \times 0,35 \mathrm{~mm} \times 0,25 \mu \mathrm{m}$ WCOT Fused Silica 7452 CP-Sil-8CB capillary column. The pressure of the carrier gas $\left(\mathrm{H}_{2}\right)$ was 110 $\mathrm{kPa}$. Injector and FID temperatures were $280^{\circ} \mathrm{C}$ and $300^{\circ} \mathrm{C}$ respectively. The temperature programme was isothermal $260^{\circ} \mathrm{C}$ for $40 \mathrm{~min}$ at least.

\section{RESULTS AND DISCUSSION}

The yield of oil extracted from hulled pumpkin seeds was found to be $48,6 \%$, and fell in the range previously reported for pumpkin seed as well as for other cucurbit seeds $(1,2,4,6,8,14)$. The freshly extracted oil was dark brown with an intense green tint in colour and had a mild nutty odour.

The physical and chemical characteristics of crude and purified pumpkin seed oil are shown in Table I. As can be seen, purification did not change the fundamental physical and chemical characteristics of the oil. The basic changes happened are referred to a reduction in acidity, colour, and unsaponifiable matter, as a result of degumming, neutralisation and bleaching. In addition, an increase in smoke point was observed which could be attributed mainly to free fatty acid reduction. Fatty acids are much more volatile than glycerides, and hence, smoke point depends on the free fatty acid content (15). The obtained values for density and refractive index are in line with those reported in literature $(2,3,4,16)$. Viscosity values were similar to those for cottonseed and olive oils and higher than those for corn, peanut and safflower oils $(15,17)$. The measured iodine values were similar to those reported previously by Lazos (4) and Lal et al. (8), but lower than those reported by Kamel et al. (2), Markovic and Bastic (3) and El-Gharbawi (16). The saponification value shows that fatty acids present in the oil have a high number of carbon atoms, and fell in the reported range $(3,4,16)$.

Table I

Physical and chemical characteristics of pumpkin seed oil

\begin{tabular}{|c|c|c|}
\hline \multirow{2}{*}{ Characteristic } & \multicolumn{2}{|c|}{ Value 1} \\
\hline & Crude & Purified \\
\hline Density, $25^{\circ} \mathrm{C}$ & $0.9182 \pm 0.018$ & $0.9175 \pm 0.021$ \\
\hline Refractive index, $40^{\circ} \mathrm{C}$ & $1.4660 \pm 0.017$ & $1.4653 \pm 0.011$ \\
\hline Viscosity $\left(21^{\circ} \mathrm{C}\right), \mathrm{mPa} . \mathrm{s}$ & $72 \pm 0.58$ & $70 \pm 0.47$ \\
\hline Smoke point, ${ }^{\circ} \mathrm{C}$ & $181 \pm 2.65$ & $205 \pm 2.18$ \\
\hline \multicolumn{3}{|l|}{ Colour } \\
\hline red units & $10.9 \pm 1.01$ & $5.0 \pm 0.90$ \\
\hline yellow units & $15.0 \pm 0.70$ & $3.2 \pm 0.47$ \\
\hline Saponification number & $201 \pm 3.72$ & $203 \pm 1.86$ \\
\hline lodine value & $107 \pm 0.58$ & $103 \pm 1.22$ \\
\hline Unsaponifiable matter, \% & $1.22 \pm 0.12$ & $0.79 \pm 0.20$ \\
\hline Acidity, $\%$ as oleic & $0.97 \pm 0.075$ & $0.04 \pm 0.03$ \\
\hline Peroxide value, $\mathrm{meq} / \mathrm{kg}$ & $9.20 \pm 0.59$ & $9.04 \pm 0.61$ \\
\hline \multicolumn{3}{|l|}{ Induction time } \\
\hline pumpkin & $5.55 \pm 0.61$ & $5.17 \pm 0.43$ \\
\hline olive & $7.22 \pm 037$ & \\
\hline sunflower & $3.40 \pm 0.41$ & \\
\hline$E_{1 \mathrm{~cm}}^{1 \%} 232$ & $6.32 \pm 0.005$ & $5.86 \pm 0.007$ \\
\hline$E_{1 \mathrm{~cm}}^{1 \%} 270$ & $3.93 \pm 0.007$ & $4.45 \pm 0.006$ \\
\hline $\mathrm{R}=E_{1 \mathrm{~cm}}^{1 \%} 232 / E_{1 \mathrm{~cm}}^{1 \%} 270$ & $1.61 \pm 0.004$ & $1.16 \pm 0.003$ \\
\hline
\end{tabular}

1 Average of three samples with three to five replications, \pm coefficient of variation. 
The fatty acid composition data presented in Table II show that linoleic (C18:2) was the major fatty acid of the pumpkin seed oil followed by oleic (C18:1), while the total unsaturated fatty acid level was $81 \%$. Total saturated fatty acids were $19 \%$ and the dominant saturated fatty acid was palmitic (C16:0). These above results were in agreement with those previously reported $(4,14,18)$, although percentages higher than $50 \%$ for linoleic acid have been reported by several authors (2, 3, 19, 20). Cirilli (21) and El-Gharbawi (16) reported that oleic acid was the predominant fatty acid
$(41-46 \%)$ followed by linoleic $(33,4-34,3 \%)$ in the pumpkin seed oil from Italy and Libya.

Furthermore, it should be pointed out that there was no change in the fatty acid pattern during purification and bleaching of the oil. Similar findings have been reported by Ogonsua and Badifu (7) for melon seed oil. However, an increase in C18:2 trans concentration, attributable to high temperature bleaching, was observed, as it was increased from a trace in the crude oil to $0,6 \%$ in purified oil (Table II). Clay bleaching at high temperatures causes cis-trans isomerization (15).

Table II

Fatty acid composition of pumpkin seed oil1

\begin{tabular}{lcc}
\hline \multicolumn{1}{c}{ Fatty acid } & \multicolumn{2}{c}{$\%$} \\
\cline { 2 - 3 } & Crude & Purified \\
\hline C14:0 & $0.11 \pm 0.036$ & $12.80 \pm 1.500$ \\
C16:0 & $12.70 \pm 0.876$ & $0.20 \pm 0.004$ \\
C16:1 cis $\omega 9$ & $0.11 \pm 0.061$ & - \\
C17:0 & Trace & $5.70 \pm 0.182$ \\
C18:0 & $6.00 \pm 0.902$ & $37.20 \pm 1.280$ \\
C18:1 9 & $38.10 \pm 0.951$ & $42.80 \pm 0.360$ \\
C18:2 & $42.10 \pm 1.121$ & $0.60 \pm 0.123$ \\
C18:2 trans & Trace & $0.10 \pm 0.017$ \\
C18:3 & $0.20 \pm 0.005$ & $0.20 \pm 0.006$ \\
C20:0 & $0.30 \pm 0.059$ & $0.10 \pm 0.026$ \\
C20:1 & $0.10 \pm 0.016$ & $0.10 \pm 0.026$ \\
C22:0 & $0.20 \pm 0.052$ & $0.10 \pm 0.036$ \\
C24:0 & Trace & Trace \\
C26:0 & $0.13 \pm 0.004$ & \\
\hline
\end{tabular}

${ }^{1}$ Average of three samples, \pm coefficient of variation.

Only a-tocopherol was detected in pumpkin seed oil, at a level of $126 \mathrm{mg} / \mathrm{kg}$. This finding confirmed what had been reported by Lazos et al (5), who reported an $a$-tocopherol concentration of $73 \mathrm{mg} / \mathrm{kg}$. It should be noted that Vogel (19), using a gaschromatographic method, reported an average of $338 \mathrm{mg} / \mathrm{kg}$ of $\beta-+\gamma-$ tocopherol, while $\alpha$ - and $\delta$-tocopherols were not found. Higher tocopherol contents averaging $437 \mathrm{mg} / \mathrm{kg}$ of pumpkin seed oil, without any reference to tocopherol form, have been reported by Schuster et al. (20). Moreover, only $a$-tocopherol at a level of 190-192 $\mathrm{mg} / \mathrm{kg}$ has been found by Ogonsua and Badifu (7) in melon seed oil. Such differences may be caused by variations in cultivar or origin. Purification and bleaching led to a reduction in $\alpha$-tocopherol content to a value of $78 \mathrm{mg} / \mathrm{kg}$, corresponding to a $62 \%$ retention. A higher tocopherol retention of $77 \%$, during pumpkin seed oil purification has been reported by Lazos et al. (5), while Ogonsua and Badifu (7) reported a retention of $52 \%$ in bleached melon seed oil. The variation in the amount of tocopherols lost during refining depends on the severity of the process with respect to temperature and time, and to crude oil condition.

The peroxide value of pumpkin seed oil was in the range adopted as satisfactory (generally less than 20 $\mathrm{meq} / \mathrm{kg}$ ). There was no change in peroxide value during purification and bleaching. A similar behaviour has been reported by Ogonsua and Badifu (7) for melon seed oil, who furthermore reported that peroxide value changes in purified oil during storage were higher than those for crude oil. A 6,8\% reduction in induction time, as measured by Rancimat, was observed (Table I), due to oil purification, which 
reduced the $a$-tocopherol content, and hence, purified pumpkin seed oil should expected to show an overall lower stability compared to crude oil.

Measurement of induction times of extra virgin olive oil and of sunflower oil along with crude pumpkin seed oil showed that olive oil had the longest induction time, 7,22 hours, and the sunflower oil the shortest, 3,40 hours (Table I). The higher oxidative stability of olive oil is related to some extent to the presence of atocopherol (23). Kiritsakis and Min (24) reported that olive oil contains between $15-150 \mathrm{mg} / \mathrm{kg}$ a-tocopherol. $a$-Tocopherol is one of the most reactive naturally occurring singlet oxygen acceptors among the four tocopherols. However, the stability of olive oil could not be explained only on the basis of tocopherol action. It is known that the olive mesocarp contains phenolic compounds, which though water soluble are present in the olive oil and considerably increase the oxidation stability of the oil (24). Although pumpkin seed oil shows a similar fatty acid profile with sunflower oil (15), the latter showed lower induction time, which could not be attributed to tocopherol content, as sunflower oil has been reported to contain higher levels of tocopherols $(636 \mathrm{mg} / \mathrm{kg})$ of which a-tocopherol accounts for $96 \%$ (608 mg/kg) (25). Moreover, it should be noted that a-tocopherol, especially in high concentrations exerts a pro-oxidant activity (26), which is explained with the formation of radicals during oxidation by gaseous oxygen, as in Rancimat. Furthermore, the higher oxidative stability of pumpkin seed oil over sunflower oil should be attributed to other constituents of non glyceride fraction of the oil, which posses antioxidant properties.
The extinctions at wavelengths of 232 and $270 \mathrm{~nm}$ as well as their ratio (R-value) are shown in Table I. It should be noted that pumpkin seed oil has considerably higher values for specific extinction in UV at both wavelengths than other vegetable oils. Similar findings have been reported by Markovic and Bastic (3), who in addition reported that oils having the same peroxide values show different values for specific extinction. Generally, R-value is higher if secondary oxidative changes are lower, i.e., the value for $E_{1 \mathrm{~cm}}^{1 \%} 270$. Laboratory purification led to a decrease in $E_{1 \mathrm{~cm}}^{1 \%} 232$ and to an increase in $E_{1 \mathrm{~cm}}^{1 \%} 270$, resulting to a decrease in Rvalue. These results confirm the findings of Vogel (19), who furthermore reported that degumming and neutralization had no actual effect on specific extinctions, while bleaching and deodourisation reduced $E_{1 \mathrm{~cm}}^{1 \%} 232$ by $40 \%$ and increased $E_{1 \mathrm{~cm}}^{1 \%} 268$ by $344 \%$.

The results of qualitative and quantitative sterol determinations in the sterolic fraction of pumpkin seed oil unsaponifiables are summarised in Table III. It is apparent that the sterol fraction from pumpkin seed oil consists mainly of $\Delta^{7}$-sterols with small proportions of $\Delta^{5}$-sterols, in spite that the sterol fractions of most vegetable oils consist mainly of $\Delta^{5}$-sterols while $\Delta^{7}$ sterols are present in small proportions $(27,28,29)$. The sterol fraction of pumpkin seed oil predominated mainly by $\Delta^{7,22,25-s t i g m a s t a t r i e n-3 \beta-o l, ~} \alpha$-spinasterol, $\Delta^{7,25}$-stigmastadienol and $\Delta^{7}$-avenasterol, followed by stigmasterol, 24-methylcholest-7-enol and $\Delta^{7}$ stigmastenol in proportions varying from 3,5 to $4,5 \%$ (Table III). These above results confirm the findings of Jeong et al. (28) and Bastic et al. (29). Oil purification and bleaching did not change the sterol pattern of the

Table III

Composition of sterol fraction of pumpkin seed oil

\begin{tabular}{lcc}
\hline \multicolumn{1}{c}{ Sterol } & & $\%$ \\
& Crude & Purified \\
\hline Cholesterol & Trace & - \\
Brassicasterol & Trace & - \\
Campesterol & $0.90 \pm 0.161$ & $0.63 \pm 0.104$ \\
Stigmasterol & $3.51 \pm 0.952$ & $3.57 \pm 0.057$ \\
24-methylcholest-7-enol & $4.50 \pm 0.234$ & $4.57 \pm 0.173$ \\
$\Delta^{7,22,25-S t i g m a s t a t r i e n-3 \beta-o l ~}$ & $22.80 \pm 1.634$ & $23.17 \pm 2.350$ \\
$\alpha$-Spinasterol & $20.20 \pm 1.134$ & $20.52 \pm 1.250$ \\
Sitostanol & $0.82 \pm 0.080$ & $0.47 \pm 0.096$ \\
Unknown & $1.00 \pm 0.259$ & $0.57 \pm 0.261$ \\
$\Delta^{5}$-Avenasterol & $0.49 \pm 0.046$ & $0.22 \pm 0.066$ \\
$\Delta^{7,25-S t i g m a s t a d i e n o l ~}$ & $23.62 \pm 5.780$ & $24.00 \pm 3.780$ \\
$\Delta^{7}$-Stigmastenol & $3.97 \pm 0.902$ & $4.03 \pm 0.988$ \\
$\Delta^{7}$-Avenasterol & $17.96 \pm 0.570$ & $18.25 \pm 0.750$ \\
Erythrodiol & $0.15 \pm 0.011$ & - \\
Uvaol & $0.14 \pm 0.085$ & - \\
\hline
\end{tabular}

1 Average of three samples, \pm coefficient of variation. 
oil due to the fact that they are relatively inert. It is known that alkali refining of oils removes a portion of the sterols (15). As a result sterols present in trace or minor amounts in crude oil were not detected in purified oil (Table III). Furthermore, it should be pointed out that $\beta$-sitosterol, present in most vegetable oils in high proportions, is absent from pumpkin seed oil as well as from the oils of other Cucurbitaceae $(27,28$, $29,30)$. Regarding the main components of the sterolic fraction, it could be concluded that there was practically no difference in composition between pumpkin seed oils of different origin.

Based on results obtained the fatty acid composition of pumpkin seed oil showed that it falls in the linoleic-oleic acid oils category and is similar and/or close to several vegetable oils like cottonseed, corn, sesame, sunflower and soybean oils (15). Therefore, pumpkin seed oil might be a good substitute for these oils in diets. The very low concentration of linolenic acid $(0,2 \%)$ might contribute to oil stability upon storage.

\section{REFERENCES}

1. Girgis, P. and Said, F. (1968). - «Lesser known Nigerian oils and fats. I. Characteristics of melon seed oils". - J. Sci. Food Agric. 19, 615-616.

2. Kamel, S. B., DeMan, M. J. and Blackman, B. (1982). - «Nutritional, fatty acid and oil characteristics of different agricultural seeds».- J. Food Technol. 17, 263269.

3. Markovic, V. V. and Bastic, L. V. (1976). - «Characteristics of pumpkin seed oil».- J. Am. Oil Chem. Soc. 53, 42-44.

4. Lazos, E. S. (1986). - "Nutritional, fatty acid and oil characteristics of pumpkin and melon seeds».- J. Food Sci. 51, 1382-1383.

5. Lazos, E. S., Tsaknis, J. and Bante, M. (1995). - Changes in pumpkin seed oil during heating".- Grasas y Aceites 46, 233-239.

6. Sawaya, N. W., Daghir, J. N. and Khan, P. (1983). - «Chemical characterization and edibility of the oil extracted from Citrullus colocynthis seeds».- J. Food Sci. 48, 104-106, 110.

7. Ogunsua, A. O. and Badifu, G. I. O. (1989). - «Stability of purified melon seed oil obtained by solvent extraction".J. Food Sci. 54, 71-73, 81.

8. Lal, B. M., Datta, N. and Madaan, T. R. (1983). -«A study of kernel oils of some cultivated cucurbits".- Qual. Plant. Foods Hum. Nutr. 32, 83-85.

9. IUPAC (1987). "Standard Methods for the Analysis of Oils, Fats and Derivatives", C. Paquat (ed.), 7th ed. Blackwell Scientific Publications.

10. Pearson's, D. (1981). - «Chemical Analysis of Foods», H. Egan, R. S. Kirk and R. Sawyer (eds.), 8th ed., pp. 520547. Churchill Livingston, Edinburgh.

11. British Standards Methods of Analysis. - «Fats and Fatty Oils, Part 1. Physical Methods, Section 1.8. Determination of smoke point".
12. Carpenter, A. P. Jr. (1979). - «Determination of tocopherols in vegetable oils".- J. Am. Oil Chem. Soc. 56, 668-671.

13. Official Journal of the European Communities. - «Determination of the composition and content of sterols by capillary-column gas chromatography", L248, 5/9/91.

14. Bemis, W. P., Berry, J. W., Kennedy, M. J., Woods, D., Moran, M. and Deutschman, A. J. Jr. (1968). -"Oil composition of Cucurbita".- J. Am. Oil Chem. Soc. 44, 429-430.

15. Swern, D. (1979). -«Bailey's Industrial Oil and Fat Products", Vols. 1 \& 2. John Wiley \& Sons, New York.

16. El-Gharbawi, M. I. (1978). -The major chemical constituents and the amino acid make-up of protein in naked pumpkin seed cake (Cucurbita pepo)". - Libyan J. Agric. 7, 53-58.

17. Lewis, M. J. (1987). -«Physical Properties of Foods and Food Processing Systems».- Ellis Horwood, London.

18. Waheed-Akhtar, M., Zafar-lqbal, M. and NadeemNawazish, M. (1980). - «Lipid class and fatty acid composition of pumpkin seed oil».- Pakistan J. Sci. Res. 32 (3/4), 295-300.

19. Vogel, P. (1978) - «Untersuchungen uber Kurbiskernol».Fette Seifen Anstrichmittel 80 (8) 315-317.

20. Schuster, W., Zipse, W. and Marquqrd, R. (1978). - «Der Einfluss von Genotyp und Anbanort auf Verschiedene Inhaltsstoffe von Samen des Olkurbis (Cucurbita pepo L.) ».- Fette Seifen Anstrichmittel 85 (2), 56-64.

21. Cirilli, G. (1971). - «Chemical characteristics of mechanically scoured pumpkin seeds».- Ind. Aliment. 10 (12), 82-84.

22. Lazos, E. S. (1986). - «Some chemical and physical characteristics of pumpkin seed oil».- Chim. Chron. New Series 15, 91-96.

23. Kiritsakis, A. (1989) - «Tocopherols». In «The Olive Oil», pp. 61-64. Agricultural Cooperative Editions, Thessaloniki, Greece.

24. Kiritsakis, A. K. and Min, D. B. (1989). - «Flavour chemistry of olive oil» In: "Flavour Chemistry of Lipid Foods», D. B. Min (ed.), pp. 196-221. The American Oil Chemists' Society, Champain, Illinois.

25. Muller-Mulot, W. (1976). - «Rapid method for the quantitative determination of individual tocopherols in oils fats". - J. Am. Oil Chem. Soc. 53, 732-736.

26. Cillard, J. and Cillard, P. (1986). -Inhibitors of the prooxidant activity of $\alpha$-tocopherol».- J. Am. Oil Chem. Soc. 63, 1165-1169.

27. Kintia, P. K. and Wojciechowski, Z. A. (1974). -«Free and bound sterols in seedlings of Cucumis sativus".Phytochemistry 13, 2235-2238.

28. Jeong, T. M., Itoh, T., Tamura, T. and Matsumoto, T. (1974). "Analysis of sterol fractions from twenty vegetable oils».- Lipids 9, 921-927.

29. Bastic, M., Bastic, LJ., Jovanovic, J. A. and Spiteller, G. (1977). - «Sterols in pumpkin seed oil».- J. Am. Oil Chem. Soc. 54, 525-527.

30. Sucrow, W. and Reimerdes, A. (1968). $-\Delta^{7}-$ Sterine aus Cucurbitaceen".- Z. Naturforsch. 23b, 42-45.

Recibido: Marzo 1997 Aceptado: Septiembre 1997 